\title{
Transatlantica
}

Revue d'études américaines. American Studies Journal

Cartographies de l'Amérique / Histoires d'esclaves

\section{Applying Durkheim to Elvis}

\section{Mark Duffett}

\section{OpenEdition}

Journals

Édition électronique

URL : https://journals.openedition.org/transatlantica/6095

DOI : 10.4000/transatlantica.6095

ISSN : 1765-2766

Éditeur

Association française d'Etudes Américaines (AFEA)

\section{Référence électronique}

Mark Duffett, « Applying Durkheim to Elvis », Transatlantica [En ligne], 2 | 2012, mis en ligne le 02 mai 2013, consulté le 06 avril 2023. URL : http://journals.openedition.org/transatlantica/6095; DOI : https://doi.org/10.4000/transatlantica.6095

Ce document a été généré automatiquement le 6 avril 2023.

\section{(c) (i) (9)}

Creative Commons - Attribution - Pas d'Utilisation Commerciale - Pas de Modification 4.0 International - CC BY-NC-ND 4.0

https://creativecommons.org/licenses/by-nc-nd/4.0/ 


\title{
Applying Durkheim to Elvis
}

\author{
Mark Duffett
}

\section{Introduction}

1 The music writer Chet Flippo once said that with Elvis Presley, we know more than we understand $(1994,8)$. In the late 1990s the Bank of Scotland combined with a merchandiser called Elvisly Yours to introduce an Elvis Mastercard. The ad for the credit card read "11.9\% APR, no fee and the power of Elvis." But what exactly is the power of Elvis and how can we study it? One way to answer that question is to examine the similarities and differences between fandom and religion. Elvis's fans are known for their passion, loyalty and vast number. Rituals like the annual candlelit walk at Graceland have evoked comparisons between Elvis fandom and religion. As one fan explained during primary research for my PhD (Duffett, 1998, 28), "I hate to mix Elvis and religion, but people that have been touched by God have that sort of feeling... it's as if you have been welcomed into a new family." The religious comparison has become a cliché and widespread joke in popular culture. For example, in his book on Elvis's image, Gilbert Rodman $(1996,7)$ noted that even "in the realm of science fiction, the image of Elvis as a religious character has become a familiar motif." In my own work (see Duffett, 2003) I have questioned the motivation for and accuracy of the religious comparison. Nevertheless, it seems appropriate to consider that if fandom can sometimes look like a form of religious fervor it may really work like one. In this piece, using the Elvis phenomenon as a case study, I will argue that there are three ways of thinking about fandom through the lens of religion: first by using limited, metaphorical strategy; second by applying a Durkheimian analysis, and third by adopting a modified, neo-Durkheimian approach. I will argue in favor of the latter strategy.

\section{A metaphorical strategy}

Because fan phenomena can sometimes look similar to moments of religious ecstasy, the idea that fandom is like a religion is a ready-made metaphor adopted and adapted 
by fans, commentators and academics. This metaphorical discourse runs the range in terms of empathy with its subject matter. Some researchers have shown empathy with the communities they describe. Daniel Cavicchi's work on Springsteen fandom is a good example. Cavicchi $(1998,42)$ uses the work of William James to compare entry into fandom to a process of religious conversion. As Cavicchi explains, "The descriptions of transformations found in narratives of becoming a fan are remarkably similar to those found in the conversion narratives of evangelical Christians in the modern United States." Other writers use the religious analogy to stereotype and lambaste fans as servile and misguided, a good example being Ted Harrison's (1992) twisted portrait of "the Elvis faith." In Harrison's totalizing logic, fans hide the religious nature of their connection for fear of ridicule, but will occasionally "come out" $(1992,75)$. From an academic perspective, Erika Doss has produced a book-length study of the Elvis phenomenon pushing the metaphor to its limits and arguing squarely that "veneration of Elvis is one strong form of religiosity" $(1999,75)$. Elsewhere (see Duffett, 2003) I have questioned this work on a number of levels which I will briefly outline here: the analogy portrays fans as servile and misguided believers. It is based on a parody that remains popular because it disparages them in order to normalize a non-fan audience. The "religiosity" idea maintains its grip by producing "evidence" that is an artifact of its own perception. Its central premise-that fandom is a religion because it looks like one-is weak because it is impossible to test conclusively in the field. Its proponents are not setting out inductively to explore, understand, or contextualize Elvis culture. When glaring differences between fandom and religion appear, advocates of the "religiosity" idea stretch definitions and discredit research subjects rather than question the merit of their framework. As a consequence, research into Elvis culture has been handicapped by a set of inappropriate ideas.

3 If the metaphorical approach to fandom as a substitute or pseudo-religion is unsatisfactory, Emile Durkheim's classic sociology offers a specific framework for the study of religion as a social system. By extension, Durkheim's work may be applicable to fans. I will look at two strategies for applying Durkheim: either wholesale or in a selective, modified way. First I will explain precisely how Durkheim viewed religion.

\section{A Durkheimian analysis}

In order to create a schema for how all religions operate in his 1912 book The Elementary Forms of Religious Life, Durkheim analyzed what he called the "primitive" totemic religions of Australian clans. In Durkheim's model, religion is not a metaphysical epiphenomenon, but is instead the generative seed of the social system. It works when social groups share a set of beliefs that separate the sacred from the profane. This cosmological belief of fundamental separation is then represented in rites, myths, and symbols. The most potent symbol is the totem, as it determines what is sacred and what is profane. Totems are material objects (sometimes people) that are worshipped by the whole group because they focus and mediate the emotional force of social collectivity. When clan members gather to worship their totem, it channels collective energy from the group back to the individual in a force which builds their personal strength and confidence. Because they are in a relation to it, they are at the heart of the clan and feel empowered. This feeling emerges by a process of social electricity that Durkheim calls effervescence. The individual's feeling of empowerment by the totem in turn engenders 
a series of moral practices and obligations that sustain the life of the collective, including the observing of various prohibitions. So from the crucible of religion, society eventually generates specialized fields, including law (as a field of moral judgment) and science (as a mode of explanation).

When applied to fandom there are some good things about the Durkheimian explanation. In his model, the only universal human need is for social companionship. Religion is not a specialized field of spiritual communion, but instead an ideological crucible that generates fundamental structures and social relations. Hence, although the French sociologist only mentioned the use of music once in his book-and then as a sound that certain clan members were not allowed to hear-some researchers have enthusiastically applied Durkheim's work directly to fan phenomena. Star performances do seem to have a totemic function in generating fan engagements. The moments of effervescence they stimulate are visible at concerts and these events in turn create new fans. Perhaps because of these similarities a few researchers have ventured to make more or less sustained wholesale analysis of music phenomena from a Durkheimian perspective. Back in 1979, for example, Bernice Martin-who has continued to write on the sociology of religion-authored an article that argued youth culture was a locus of "the sacred" and that stars were totems celebrating individualism. As she explained, "The fan clubs and fan magazines are some of the most obviously ritual elements in rock... The role of the Pop stars [sic] too has strong ritual and religious overtones: 'Clapton is God' is one of the (only half jocular) slogans that Cream fans used to use" $(1979,108)$. In 2005 Alexander Riley argued that gangsta rap was concerned with a particular notion of the tragic and that the mass wave of grief associated with the death of key rappers could be seen as a piacular rite in Durkheim's sense. He explained, "These mourning rites obviously are expressed in different ways that outwardly invoke sadness and loss ('dejection, cries, and tears'), but their effect is precisely the same kind of collective effervescence that Durkheim notes in the positive cult" (Riley, 2005, 305). Even more recently, Rupert Till (2010) has used Durkheim's work to argue that Prince "is part of, and also a result of, a spiritual revolution resulting from the emergence of postmodernity, in which popular cultural artifacts are fulfilling roles traditionally associated with religions" $(2010,76)$.

There are some serious problems with applying Durkheim to fandom which scholars like Martin, Riley and Till do not seem to have quite taken into account. First, for Durkheim religions are defined by the sacred $(2008,37)$. The fundamental, structuring conceptual division between the sacred and profane does not map well on to the sociology of fandom. As Cornel Sandvoss noted in his 2005 book Fans: The Mirror of Consumption, "In contrast to religion, fandom lacks an absolute, other-worldly framework through which social realities are constructed and legitimated" $(2005,63)$. It can be added here that all religions, for Durkheim, contain a notion of the afterlife (Durkheim, 2008, 183). Second, a seeming barrier to the idea of effervescence is that fandom can begin in private acts of engagement with a text, although I would argue here that mass commodities-with their inherent notions of audiencehood-can function as perceived social occasions. Third, in the Durkheimian schema, the function of effervescence is to both empower members of the community and produce the moral code by which they protect the group's interests. Totems are crucial here, as they decide what is sacred and what is profane (Durkheim, 2008, 96). There has been academic work on the way that Elvis fans and others have perceived information to 
ignore certain interpretations which damage their interests (see Fraser and Brown, 2002). However, even if specific communities of fans definitely develop their own ethics, their celebrity icons can be subject to wider moral censure-John Lennon's profaning "bigger than Jesus" comment springs to mind-and fandom does not seem to be totally governed by prohibitions.

\section{A neo-Durkheimian approach}

7 We can, then, begin to see a third strategy with which to frame fandom: the use of a selective, modified version of Durkheim's approach. The first aspect of this would replace the sacred / profane dichotomy (which is characterized by the contagiousness of the sacred), with a continuum between: being distant with the star and being intimate with them. For Durkheim the human voice allows a connection because it creates a certain kind of intimacy: "the exhaled breath establishes a connection since it is part of us that is released to the outside" $(2008,226)$. The second aspect of a neo-Durkheimian approach would be to retain an interest in the circuit of energy that feeds from the mass audience to the performer and back to the individual fan. As Durkheim explains about the totem:

This unusual surplus of forces is quite real: it comes to him from the very group he is addressing. The feelings provoked by his speech return to him inflated and amplified, reinforcing his own. The passionate energies he arouses echo back to him and increase his vitality. He is no longer a simple individual speaking, he is a group incarnate and personified. $(2008,158)$

This paragraph could just as well be a review of Elvis's 1968 TV Comeback Special as a statement on the sociology of religion. Reviewing another concert one reviewer reported, "When he starts to shake, the crowd bursts into a frenzy of squeals" (Gordon, 1996, 35). We might also agree that while fans participate in this energizing loop of human interaction, just like clan members they are blind to the source of their totem's power. In that sense fandom is like a religion, because for Durkheim "religion is above all a system of notions by which individual imagine the society to which they belong and their obscure yet intimate relations with that society" $(2008,170)$. In the case of Elvis fandom, this means that the fans see his talent-his voice, his physical presenceas the source of his power. They reify the social relations by ignoring the centrality of his function as social mediator. For example, as Robert Gordon explained in one book for fans, "It is a testament to this one human being's power that his following has not diminished in the years since his death" $(1996,200)$.

9 To use Durkheim's words, Elvis and his fans can be seen to "form an interdependent system in which all parts are linked and vibrate sympathetically" (116). This makes fandom a case of joining the system. Sometimes it happens when listeners who are already engaged by aspects of the performance are transformed into fans by recognizing the vast size of the collective. One branch leader who had listened to his wife playing Elvis records for many years before he became hooked, explained to me during my $\mathrm{PhD}$ research:

If I actually name the day I became an Elvis fan, the moment I became an Elvis fan was at the Leicester convention... They played American Trilogy. Some guy grabbed my hand and pulled me up to my feet. I felt this adrenaline go through from the top of my head to the bottom of my feet and it was just an astonishing feeling of 
brotherhood, almost, in the room. Just this family, you were in amongst this family. (Duffett, 1998, 29) attachment. As Durkheim explained it, the totem has a crucial role in that:

We may imagine an object as worthy of being loved and desired, but it does not follow that we feel stronger for that. This object must release energies superior to those we have at our disposal, and, in addition, we must have some way of making them enter us and mingle with our inner life" $(2008,312)$.

11 Music provides a vehicle for that, which is why it is discussed in terms of power and intimacy. As one fan listening to his favorite song during my PhD research put it, "If you listen to that song, it's got all the ranges of his voice in it. It's just so powerful: the high and the low." Another fan speaking to Elvis researcher Julia Aparin $(1988,78)$ explained, "Elvis's music is different. It's like it comes from inside him to inside you." That intimate moment of affective engagement then gives fans a stock of energy that can get them through the trauma of illness, divorce, and bereavement.

12 I have suggested that a modified version of Durkheim's sociology of religion can be applied to Elvis fan culture. Furthermore, I wish to argue this neo-Durkheimian model can be extended to other fan cultures. To do this I will finish with some quotations from a recent BBC Imagine documentary on Elvis's friend, the Welsh entertainer Tom Jones (Imagine: Jones the Voice aired on July $6^{\text {th }} 2010$ ). Please note the expressions, first, of reification (that Tom's power comes from Tom), second, of intimacy, and third, of the social production of energy:

Cerys Matthews on Tom's voice: It is like standing next to the tube coming in on the underground; it's just this sheer energy that comes rumbling up from somewhere. Jools Holland on Tom's voice: He's got the elements of someone like Caruso-an opera singer-because he has that power, but he also, more importantly, has the sensibility of a soul singer or a rock'n'roll singer... The thing about the human voice is that it's the one instrument that all of us have and all of us carry with us. Tom: he has a very powerful voice, but that doesn't make a great voice. What makes a great voice is where it comes from-it comes from the heart-so when he sings a song, as well as having a beautiful voice, he believes the song. He has to believe in the song to be able to sing it, so that you the listener are taken into the song. Really, only the very great singers have that.

Tom Jones on live performance: It's a high that you just don't get from anything else. When you're on there, and the band and the people, and it's like-wow!-you've gone into another place. And I think any true performer would say, "I don't want that to stop."

\section{BIBLIOGRAPHIE}

APARIN, Julia, He Never Got Above His Raising: An Ethnographic Study of A Working Class Response to Elvis Presley, Ph.D., University of Pennsylvania, 1988.

CAVICCHI, Daniel, Tramp Like Us: Music and Meaning Among Springsteen Fans, New York, Oxford University Press, 1998. 
DOSS, Erika, Elvis Culture: Fans, Faith \& Image, Lawrence, University of Kansas Press, 1999.

DUFFETT, Mark, Understanding Elvis: Presley, Power and Performance, Ph.D., University of Wales, 1998.

---, "False Faith or False Comparison? A Critique of the Religious Interpretation of Elvis Fan Culture" in Popular Music and Society 26, 4, 2003, 513-22.

DURKHEIM, Émile, The Elementary Forms of Religious Life, Oxford, Oxford University Press, 2008 (1912).

FLIPPO, Chet, Graceland: The Living Legacy of Elvis Presley, London, Hamlyn, 1994.

FRASER, Benson, P., and William J. Brown, "Media, celebrities, and social influence: Identification with Elvis Presley" in Mass Communication \& Society 5, 2002, 185-208.

GORDON, Robert and Michael Evans, The King On The Road: Live On Tour 1954 To 1977, London, Hamlyn, 1996.

HARRISON, Ted, Elvis People: The Cult of the King, London, Fount Press, 1992.

Imagine: Jones the Voice, BBC, July $6^{\text {th }} 2010$.

MARTIN, Bernice, "The Sacralization of Disorder: Symbolism in Rock Music" in Sociological Analysis 40, 2, 1979, 87-124.

RILEY, Alexander, "The Rebirth of Tragedy out of the Spirit of Hip-hop: A Cultural Sociology of Gangsta Rap" in Journal of Youth Studies 8, 3, 2005, 297-311.

SANDVOSS, Cornel, Fans: The Mirror of Consumption, London, Polity Press, 2005.

TILL, Rupert, "Pop Stars and Idolatry: An Investigation of the Worship of Popular Music Icons, and the Music and Cult of Prince" in Journal of Beliefs and Values 31, 1, 2010, 69-80.

\section{RÉSUMÉS}

Elvis Presley a depuis le début attiré un public de fans et nombreux et fidèles. Dans cet article, je démontre que s'il n'est pas possible d'en faire une divinité, il est néanmoins possible d'utiliser la théorie durkheimienne de la religion totémique pour mieux comprendre le phénomène. Mon argument est que les fans offrent leur attention collective à Elvis en échange de l'excitation d'une rencontre réelle ou imaginaire avec la star. En d'autres termes, la popularité d'Elvis est depuis toujours le médium grâce auquel son talent musical s'est actualisé. Elvis n'en est pas pour autant "sacré », objet d'adoration comme un «dieu». Son aura repose sur sa capacité, en tant qu'individu, à canaliser l'excitation générée par la rencontre avec une célébrité. Le mythe du jeune rural devenu célèbre renforce cet effet et transforme Elvis en star iconique par excellence.

Elvis Presley has always had a very prominent and loyal fan following. In this article I argue that although Elvis fans are not substituting him for a deity, we can use one mechanism from Emile Durkheim's theory of totemic religion to understand the human chemistry of his phenomenon. Specifically, I argue that fans offer their collective attention to Elvis in exchange for the thrill of a real or imagined individual encounter with him as a star of such magnitude. In other words, Elvis's popularity is not incidental to his phenomenon, but has always been the medium through which his music talent has actualized itself. This does not make Elvis "sacred," like a "god" or an object of worship. His entertainment is so thrilling because he, as an individual, adeptly channels the "buzz" of meeting someone so famous. His myth as a humble country boy also intensifies the thrill, making Elvis the ultimate popular icon. 
INDEX

Keywords : Audience, Elvis Presley, Émile Durkheim, Fandom, Music, Power

Mots-clés : amateurs, Elvis Presley, Émile Durkheim, fans, musique rock, spectateurs

Thèmes : La boîte à musique

\section{AUTEUR}

MARK DUFFETT

University of Chester 